Egyptian Journal of Rabbit Science, 31(2): 199-215 (2021)

\title{
GENERAL AND SPECIFIC COMBINING ABILITY OF GROWTH PERFORMANCE ATTRIBUTES IN RABBITS
}

\author{
Kariman ${ }^{1}$, Farg. M.; Gouda ${ }^{2}$, G.F.; El-Kelawy ${ }^{1}$ H.M. and Tawfeek ${ }^{1}$, M.I. \\ ${ }^{1}$ Department of Animal and Poultry Production, Faculty of Technology \& \\ Development, Zagazig University, Zagazig Egypt. \\ ${ }^{2}$ Animal Production Department, Faculty of Agriculture, Ain Shams \\ University, Shoubra El-Kheima, 11241 Cairo Egypt \\ Corresponding_Email:_gouda_fathi@yahoo.com,mostawms@hotmail.com, \\ drhassan_2105@yahoo.com
}

ABSTRACT:

This work aimed to estimate general (GCA) and specific (SCA) combining ability and reciprocal crosses $(R C)$ effects on rabbit growth performance attributes from weaning to marketing to recognize the best suitable crossbred for rabbit breeder to use in rabbit meat production under Egyptian circumstances. A total of 123 male (59) and female (64) rabbits represents three breeds and their diallel crosses were used in this study. The pure breeds were New Zealand White (N), Papillon (P) and Flemish Giant $(F)$. The six crossbreeds were NF, NP, FP, FN, PN, $P F$. The growth performance attributes were body weights at $4\left(B W_{4}\right), 8$ $\left(B W_{8}\right)$ and $12\left(B W_{12}\right)$ weeks of age, daily weight gain between 4 and 8 weeks $\left(D G_{4-8}\right), 8$ and 12 weeks $\left(D G_{8-12}\right)$ and between 4 and 12 weeks $\left(D G_{4-12}\right)$ and relative growth rate $(R G)$ at the same interval ages $\left(R G_{4-8}\right.$, $R G_{8-12}$ and $R G_{4-12}$ ).

The present results showed positive interrelationship among all body weight traits. However, $B W_{8}$ was highly correlated with $D G$ at all studied ages ( $r=0.61$ to 0.91). There is highly negative correlation between BW4 and RG at 4-8wks and 4-12 wks of age. The genotype had significant effect on body weight at 8 and 12 weeks of age. $N$ rabbits were recorded to be the heaviest breed at weaning (4 weeks), while $P N$ and FN crosses were recorded to be the heaviest rabbits at market (12 weeks). Genetic groups were found to had highly significant effect on $D G$ and $R G$, during all intervals age. On the other hand, effect of sex on $B W, D G$ and $R G$ of growing rabbits were not significant at studied intervals. Insignificant effect for GCA, SCA and RC on BW were recorded at different ages, except for the reciprocal cross effect at 12 weeks of age. The NP crossbred seemed to be the best cross combination in improving of $B W$. GCA, SCA and RC had significant effect $(P<0.05$ or 0.001) on DG and RG. FN crossbred was found to be the best 
genetic group among all crosses for $D G$ and $R G$.

Conclusively, the results obtained in present study suggested that Papillon is a promising breed in crossbreeding program regarding growth performance traits. Crossing of New Zealand White as a sire breed with Papillon as a dam breed, NP, would be recommended over other crosses to improve marketing weight in rabbits. However, Crossing of Flemish Giant as a sire breed with New Zealand White as a dam breed, FN, would be recommended over other crosses to improve growth rates in rabbits especially in case of marketing rabbits at constant weight to save time and cost.

Keywords: Rabbits, Growth traits, General \& specific combining ability.

\section{INTRODUCTION}

Rabbit is a small livestock species, which makes it a desirable meat producing animal. For its small body size, rabbits need a reduced space and feed. It characterized by short generation, high feed conversion efficiency and faster growth rate with high prolificacy. These characteristics made the rabbit as ideal species for meat production (Bora et al., 2010) compared to other livestock species.

Enhancement in rabbit breeds performance can be achieved through selection or crossbreeding. A lot of benefits can be gained from hybridization and from break of the cumulated inbreeding, which may have occurred during continued selection process and genetic improvement of growth performance attributes (Adenaike, 2013).

A diallel cross is a cornerstone tool applied to evaluate the performance of breeds in their various combinations, especially for those native breeds (Dickerson, 1993).

Combining ability was defined as favorable genes (or features) that are transmitted to their offspring (Rojas and Sprague, 1952). In quantitative genetics, two types of combining ability, general (GCA) and specific (SCA), have been established. GCA may refers to additive effects and additive interactions, while SCA may indicate dominance and epistasis (Rojas and Sprague, 1952). GCA used to denominate the average performance of crossbred line in cross combinations, while SCA used to denominate those cases in which certain combinations do comparatively better or inferior to would be expected based on the average performance of the lines indicated (Kabir et al., 2011). According to Sprague and Tatum (1942), GCA occurred due to the additive effect of genes while SCA occurred because of epistatic or dominance effect of these genes (Kabir et al., 2012). Combining ability are valuable to recognize the nature of genetic variance (El-Bayomi et al., 2012) 
and assisting the breeder in choosing suitable parents for improving either lack of information about the effect of crossbreeding in rabbits including Papillon breed was noticed.

Therefore, objective of present work was to examine general and specific combining ability for growth performance attributes of rabbits including Papillon breed, underneath Egyptian conditions.

\section{MATERIALS AND METHODS}

\section{Source of data:}

A total rabbits of 12 New Zealand White (N),13 Papillon (P) and 12 Flemish Giant (F), as well as their direct crosses viz 18 NF, 12 NP and 15 FP with their reciprocal crosses viz $13 \mathrm{FN}, 14 \mathrm{PN}$ and $14 \mathrm{PF}$ were chosen randomly at weaning (4-weeks of age) and raised to marketing age (at 12 weeks of age ) to investigate the effect of general and specific combining ability for some growth performance attributes of rabbits, under Egyptian environmental circumstances. The rabbit records were obtained from private rabbit farm in Qalyubia Governorate, Egypt.

\section{Management of animals:}

The experimental rabbits were kept in the same managerial, hygienic, and housing conditions and housed provided with feeders and automatic drinkers. Throughout the experimental period from weaning at 4-weeks to marketing at 12 -weeks of age. Feed and clean water were provided ad libitum. They were fed acommercial pelleted diets providing $18 \%$ crude protein and $2800 \mathrm{KCal}$. digestible energy/kg diet until marketing age.

\section{The measured traits}

\section{Growth performance attributes:}

1. Body weight (BW) at 4, 8 and 12 weeks of age.

2. Daily body weight gain (DG), during the period from 4-8, 8-12 and 4-12 wks.

3. Relative growth rate (RG) during the period from 4-8, 8-12 and 4-12 wks, according to Eman ( 2011).

\section{Data analysis}

Data were analyzed using proc GLM of SAS software (SAS institute, 2011) according to the following statistical model:

$$
Y_{I J K}=\mu+G_{i}+S_{j}+e_{i j k}
$$

Where: $Y_{i j k}=$ the observed value, $\mu=$ Overall mean, $G_{i}=i^{t h}$ Effect of genotype $(i=1,2,3 . .9), S_{j}=j^{\text {th }}$ Effect of sex $(j=1,2)$ and $e_{i j k}=$ Random error assumed to be N.I.D $(0, \sigma 2 \mathrm{e})$. 
General and specific combining abilities were estimated by GSCA 1.0 program package software (Tong et al., 2012) with Griffing's method I according to the following model:

Where:

$$
Y_{I J M}=\mu+G_{i}+G_{j}+S_{i j}+R_{i j}+e_{i j m}
$$

$\mathrm{Y}_{\mathrm{ijm}} \quad=$ The $\mathrm{m}^{\text {th }}$ observation of the $\mathrm{ij}^{\text {th }}$ cross; $\mu$ is the overall mean,

$\mathrm{G}_{\mathrm{i}}$ and $\mathrm{G}_{\mathrm{j}}=$ Effect of general combining ability of the $\mathrm{i}^{\text {th }}$ and $\mathrm{j}^{\text {th }}$ parents, respectively,

$\mathrm{S}_{\mathrm{ij}} \quad=$ The specific combining ability effect of the $\mathrm{i}^{\text {th }}$ and $\mathrm{j}^{\text {th }}$ parents that satisfies $S_{\mathrm{ij}}=\mathrm{S}_{\mathrm{ji}}$ if both exist,

$\mathrm{R}_{\mathrm{ij}} \quad=$ Reciprocal effect for the $\mathrm{i}^{\text {th }}$ and $\mathrm{j}^{\text {th }}$ parents, and

$\mathrm{e}_{\mathrm{ijm}}=$ The error term assumed to be N.I.D $\left(0, \sigma^{2} \mathrm{e}\right)$

\section{RESULTS AND DISCUSSION}

\section{Means and coefficients of variation:}

Mean and coefficient of variation $(\mathrm{CV} \%)$ for growth performance attributes are showed in Table 1. It appeared that the higher the age of animal, the smaller the variability in growth characteristics. As general trend, $\mathrm{BW}_{4}$ was found to be more variable than older ages $\left(\mathrm{BW}_{8}\right.$ and $\left.\mathrm{BW}_{12}\right)$ for all genotypes. For example, in pure breeds, the CV\% of live body weight ranged from 14.70 to $28.41,12.30$ to 30.98 and 5.45 to 8.15 in NN, PP and FF, respectively. Comparable trend of variability for body weight was previously reported by Ezzeroug et al. (2019) on synthetic line, Peiró et al. (2019) on synthetic line and Sakthivel et al. (2017) on New Zealand rabbits for weaning weight $(\mathrm{CV} \%=28,23.9$ and 25.35, respectively) and marketing weight $(\mathrm{CV} \%=21,13.8$ and 14.45 , respectively).

With few exceptions, the same trend of phenotypic variation was observed for daily gain and relative growth rate (Table 1, Sakthivel et al., 2017). The higher variability at early age compared to the older age may be due to the maternal effect on the kids through pre-weaning age, which extends until weaning at 4 weeks.

\section{Simple correlation among growth performance attributes:}

Simple correlation among the growth performance attributes is presented in Table 2. The results showed that rabbits which appeared to be heavier through the older age at $8 \mathrm{wks}(\mathrm{r}=0.704)$ and at marketing at $12 \mathrm{wks}$ $(r=0.627)$ were heavier at weaning weight. 


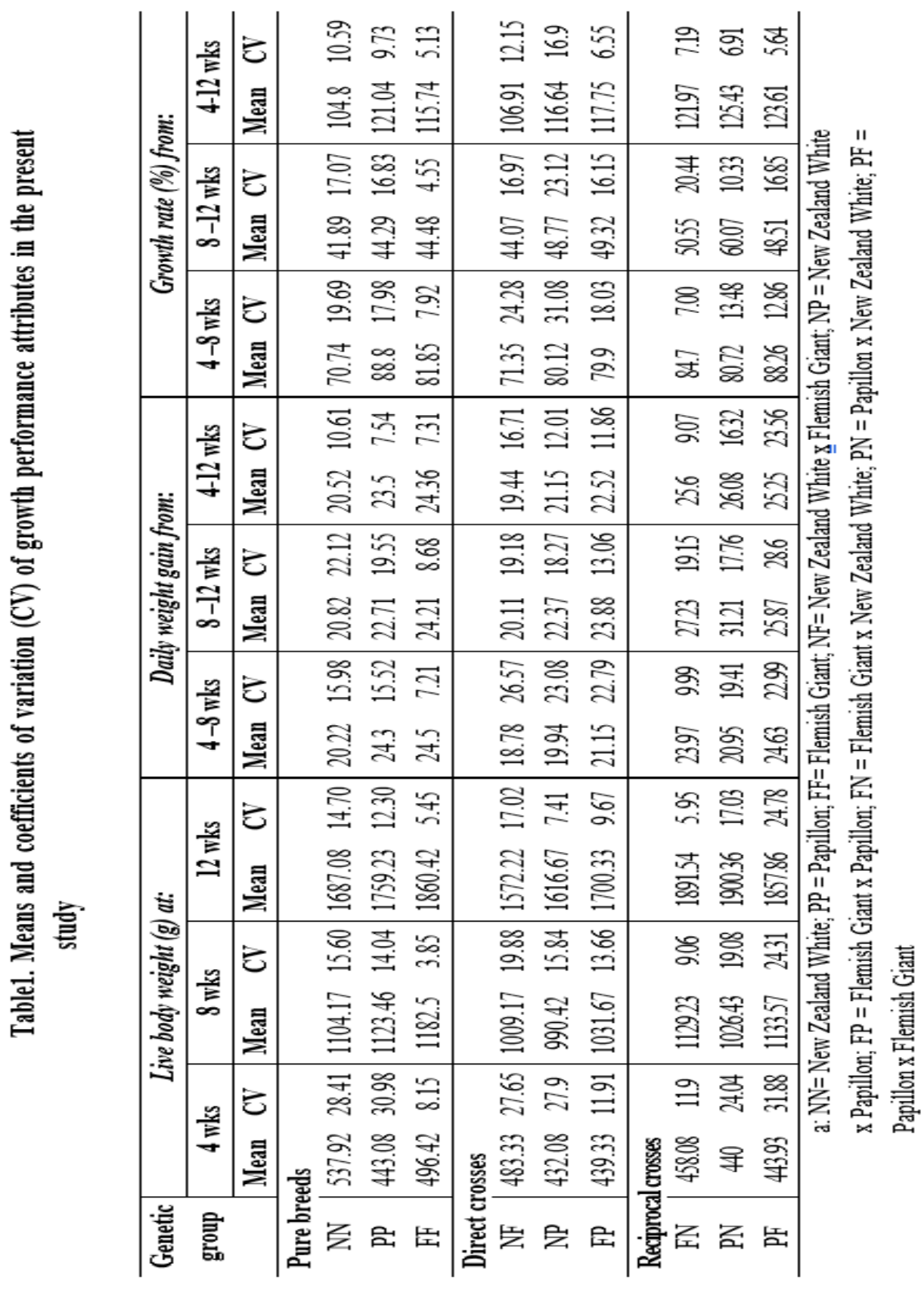


KARIMAN FARG et al.

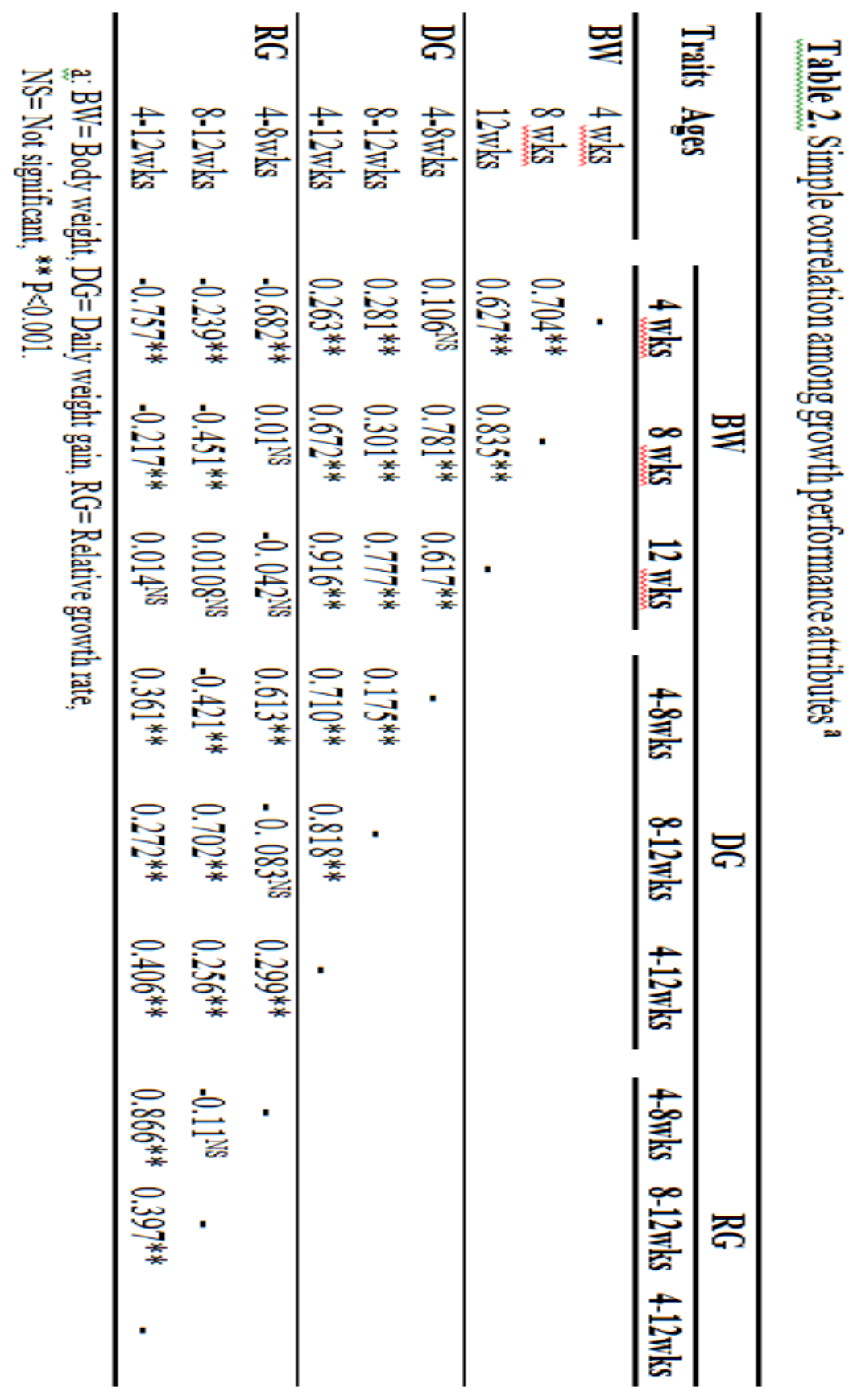


There is negative relationship between weaning weight and relative growth rate during all age intervals $(r=-0.239$ to -0.757$)$. In case of marketing at fixed age, the rabbits with faster daily gain during the period 812 wks of age seemed to have faster relative growth rate during the same period $(r=0.7)$. Similar previous results, in agreement with present study, were reported positive highly correlation between weaning weight and slaughter weight (Ezzeroug et al., 2019 and Hanaa et al., 2014). However, in contrast, Shemies and Abdallah (2000) obtained negligible phenotypic correlation between weaning weight and marketing age on New Zealand White rabbit breed $(\mathrm{r}=0.11)$.

\section{Breed effect on growth performance attributes}

\section{Body weight $(B W)$ :}

Table (3) cleared that breed effect was significant $(P<0.05)$ on body weight at $8^{\text {th }}$ and $12^{\text {th }}$ weeks of age and insignificant at $4^{\text {th }}$ weeks of age $(P>0.05)$.

However, $\mathrm{PN}$ and FN crosses rabbits were recorded to have the heaviest market weight at 12 weeks of age (1900.5236 and $1891.54 \mathrm{~g}$, respectively). Eady (2003) observed significant breed difference for weaning weight in a crossbreeding experiment involved New Zealand White, Californian, and Flemish Giant breeds. Rania Hassan (2005) worked with Gray Giant Flander in a crossbreeding experiment and observed that, it was the heaviest breed at 8 and 10 weeks of age.

The superiority of FN and PN crossbred rabbits at weaning and marketing weight indicates superiority of New Zealand White rabbits as dam breed (Prayaga and Eady, 2002; El-Bayomi et al., 2012). These findings illustrated the good mothering ability of New Zealand White breed.

Effect of sex (Table 3) on live body weight (g) of growing rabbits was not significant at different studied ages.

\section{Daily weight gain $(D G)$ :}

Table (4) showed that, breed effect was highly significant $(P<0.001)$ on $\mathrm{DG}_{4-8}, \mathrm{DG}_{8-12}$, and $\mathrm{DG}_{4-12}$. The means of $\mathrm{PP}$ and $\mathrm{FF}$ as purebreds were higher significantly faster gain than $\mathrm{NN}$ for DG at different periods studied.

On the other hand, PN crossbred rabbits during the period from 8-12 weeks of age and FN rabbits from the periods 4-12 wks were recorded to be the faster DG (g/day) as compared to the other genetic groups (Table 4). Eady (2003) reported significance differences for weaning weight in a crossbreeding experiment involved $\mathrm{N}, \mathrm{C}$ and $\mathrm{F}$. 
Table 3. Effect of genetic group and sex on live body weight $(\mathrm{g})$ of rabbits from weaning to marketing

\begin{tabular}{|c|c|c|c|c|}
\hline \multirow[b]{2}{*}{ Genetic groups } & \multirow[b]{2}{*}{ No. } & \multicolumn{3}{|c|}{ Live body weight $(\mathrm{g})^{\mathrm{a}}$ at } \\
\hline & & $4 \mathrm{wks}$ & 8wks & $12 \mathrm{wks}$ \\
\hline $\mathrm{NN}$ & 12 & 537.92 & $1104.17^{\text {ab }}$ & $1687.08^{\mathbf{a b}}$ \\
\hline PP & 13 & 443.08 & $1123.46^{\text {ab }}$ & $1759.23^{\text {ab }}$ \\
\hline FF & 12 & 496.42 & $1182.5^{\mathrm{a}}$ & $1860.42^{a}$ \\
\hline NF & 18 & 483.33 & $1009.17^{b}$ & $1572.22^{b}$ \\
\hline NP & 12 & 432.08 & $990.42^{b}$ & $1616.67^{b}$ \\
\hline FP & 15 & 439.33 & $1031.67^{b}$ & $1700.33^{\text {ab }}$ \\
\hline FN & 13 & 458.08 & $1129.23^{\text {ab }}$ & $1891.54^{\mathrm{a}}$ \\
\hline $\mathrm{PF}$ & 14 & 443.93 & $1133.57^{\mathbf{a b}}$ & $1857.86^{\mathrm{a}}$ \\
\hline $\mathrm{PN}$ & 14 & 440.00 & $1026.43^{b}$ & $1900.36^{\mathrm{a}}$ \\
\hline Sig. test & & NS & $*$ & $*$ \\
\hline \multicolumn{5}{|l|}{ Sex } \\
\hline Male & 59 & 465.08 & 1069.41 & 1736.95 \\
\hline Female & 64 & 461.52 & 1084.30 & 1771.41 \\
\hline Sig. test & & NS & NS & $\mathrm{NS}$ \\
\hline
\end{tabular}

a: Means in the same column within the same classification have bearing different letters, differed significantly $(\mathrm{P}<0.05)$; $\mathrm{NS}=$ Not significant and $*=\mathrm{P}<0.05$;

$\mathrm{NN}=$ New Zealand White; $\mathrm{PP}=$ Papillon; $\mathrm{FF}=$ Flemish Giant; NF= New Zealand White $\mathrm{x}$ Flemish; $\mathrm{NP}=$ New Zealand White $\mathrm{x}$ Papillon; FP = Flemish Giant $\mathrm{x}$ Papillon; FN = Flemish Giant $\mathrm{x}$ New Zealand White; $\mathrm{PF}=$ Papillon $\mathrm{x}$ Flemish Giant; PN = Papillon $\mathrm{x}$ New Zealand White

In a crossbreeding experiment, Rania Hassan (2005) found that the Gray Giant Flander was the heaviest breed at 8 and 10 weeks of age. The superiority of PN and FN crossbred rabbits indicates the superiority of $\mathrm{N}$ as dam breed for improving DG at marketing age. Eman (2011) recorded similar significant breed difference for DG in a crossbreeding experiment at 8-10 weeks of age.

Insignificant effect of sex on body weight gain (g/day) of growing rabbits was noticed at different studied ages.

\section{Relative growth rate $(R G)$ :}

Data in Table (5) showed that, breed effect was highly significant $(P<0.01$ or 0.001$)$ on RG, during all interval ages. The means of PP and FF as purebreds were significantly faster growing than NN. However, PN 
Table 4. Effect of genetic group and sex on daily weight gain (g/day) of rabbits from weaning to marketing.

\begin{tabular}{|c|c|c|c|c|}
\hline \multirow{2}{*}{$\begin{array}{c}\text { Genetic } \\
\text { group }\end{array}$} & \multicolumn{4}{|c|}{ Daily weight gain (g/day) ${ }^{\mathrm{a}}$ at } \\
\hline & No. & 4weeks & 8weeks & 12weeks \\
\hline $\mathrm{NN}$ & 12 & $20.22^{c}$ & $20.82^{\mathrm{de}}$ & $20.52^{\mathrm{de}}$ \\
\hline PP & 13 & $24.30^{\mathrm{ab}}$ & $22.71^{\text {cde }}$ & $23.50^{\mathrm{abc}}$ \\
\hline FF & 12 & $24.50^{\mathrm{ab}}$ & $24.21^{\mathrm{bcd}}$ & $24.36^{\mathrm{ab}}$ \\
\hline NF & 18 & $18.78^{c}$ & $20.11^{\mathrm{e}}$ & $19.44^{\mathrm{e}}$ \\
\hline NP & 12 & $19.94^{c}$ & $22.37^{\mathrm{cde}}$ & $21.15^{\text {cde }}$ \\
\hline FP & 15 & $21.15^{a b c}$ & $23.88^{\text {bcde }}$ & $22.52^{\text {bcd }}$ \\
\hline FN & 13 & $23.97^{\mathrm{ab}}$ & $27.23^{b}$ & $25.60^{\mathrm{a}}$ \\
\hline $\mathrm{PF}$ & 14 & $24.63^{\mathrm{a}}$ & $25.88^{b c}$ & $25.25^{\mathrm{a}}$ \\
\hline $\mathrm{PN}$ & 14 & $20.95^{\mathrm{bc}}$ & $31.21^{\mathrm{a}}$ & $26.08^{a}$ \\
\hline Sig. test & & $* * *$ & $* * *$ & $* * *$ \\
\hline \multicolumn{5}{|l|}{ Sex } \\
\hline Male & 59 & $21.58 \pm .60$ & $23.84 \pm .71$ & $22.71 \pm .48$ \\
\hline Female & 64 & $22.24 \pm .58$ & $24.54 \pm .73$ & $23.39 \pm .52$ \\
\hline Sig. test & & $\mathrm{NS}$ & NS & NS \\
\hline
\end{tabular}

crossbred rabbits were recorded 60.07 and $125.43 \%$ of relative growth rate, during intervals of 8-12 and 4-12 weeks of age, respectively, when compared the other breed groups. Abdel-Hamid (2007) recorded superiority of crossbred New Zealand White x Californian (70.97\%) over than reciprocal crossbred Cal x NZW (54.22\%) during period 4-6 weeks of age. On the contrary, Eman (2011) reported superiority of Cal x NZW (52.71\%) cross over than NZW x Cal (47.56\%) cross, during 4-6 wks of age and recorded significant breed difference for RG.

Effect of sex on RG of growing rabbits were not significant at studied ages (Table 5).

General and specific combining abilities for growth performance attributes:

\section{Body weight}

Table 6 showed insignificant differences for General combining ability (GCA), specific combining ability (SCA) and reciprocal cross effects for all studied traits, except for the reciprocal cross $\mathrm{BW}_{12}(\mathrm{P}<.001)$. Similar results for GCA on body weight were previously reported (El- 
Table 5. Effect of genetic group and sex on relative growth rate of rabbits from weaning to marketing

\begin{tabular}{|c|c|c|c|c|}
\hline \multirow{2}{*}{$\begin{array}{l}\text { Genetic } \\
\text { group }\end{array}$} & \multicolumn{4}{|c|}{ Relative growth rate from : $^{\text {a }}$} \\
\hline & No. & 4weeks & 8weeks & 12weeks \\
\hline $\mathrm{NN}$ & 12 & $70.74 \pm 4.02^{b}$ & $41.89 \pm 2.06^{\mathbf{c}}$ & $104.80 \pm 3.21^{\mathrm{b}}$ \\
\hline PP & 13 & $88.80 \pm 4.43^{a}$ & $44.27 \pm 2.07^{b c}$ & $121.04 \pm 3.27^{\mathrm{a}}$ \\
\hline FF & 12 & $81.85 \pm 1.87^{\text {ab }}$ & $44.48 \pm .58^{\mathrm{bc}}$ & $115.74 \pm 1.71^{\mathrm{a}}$ \\
\hline NF & 18 & $71.35 \pm 4.08^{b}$ & $44.07 \pm 1.76^{b c}$ & $106.91 \pm 3.06^{b}$ \\
\hline NP & 12 & $80.12 \pm 7.19^{\text {ab }}$ & $48.77 \pm 3.25^{b c}$ & $116.64 \pm 5.69^{a}$ \\
\hline FP & 15 & $79.90 \pm 3.72^{a b}$ & $49.32 \pm 2.06^{b}$ & $117.75 \pm 1.99^{\mathrm{a}}$ \\
\hline FN & 13 & $84.70 \pm 1.64^{\mathrm{a}}$ & $50.55 \pm 2.86^{b}$ & $121.97 \pm 2.43^{\mathrm{a}}$ \\
\hline $\mathrm{PF}$ & 14 & $88.26 \pm 3.03^{a}$ & $48.51 \pm 2.18^{b c}$ & $123.61 \pm 1.86^{\mathrm{a}}$ \\
\hline $\mathrm{PN}$ & 14 & $80.72 \pm 2.91^{\text {ab }}$ & $60.07 \pm 1.66^{\mathrm{a}}$ & $125.43 \pm 2.32^{\mathrm{a}}$ \\
\hline Sig. test & & $* * *$ & $* *$ & $* * *$ \\
\hline \multicolumn{5}{|l|}{ Sex } \\
\hline Male & 59 & $79.81 \pm 2.21$ & $47.83 \pm 1.27$ & $116.20 \pm 1.83$ \\
\hline Female & 64 & $81.06 \pm 1.73$ & $48.22 \pm 1.1$ & $117.60 \pm 1.43$ \\
\hline Sig. test & & $\mathrm{NS}$ & $\overline{\mathrm{NS}}$ & $\overline{N S}$ \\
\hline
\end{tabular}

a: Means in the same column within the same classification have bearing different letters, differed significantly $(\mathrm{P}<0.05)$; NS= Not significant and $* *=\mathrm{P}<0.01$, $* * *=\mathrm{P}<0.001$;

$\mathrm{NN}=$ New Zealand White; $\mathrm{PP}=$ Papillon; $\mathrm{FF}=$ Flemish Giant; NF= New Zealand White $\mathrm{x}$ Flemish; NP = New Zealand White $\mathrm{x}$ Papillon; FP = Flemish Giant $\mathrm{x}$ Papillon; FN = Flemish Giant $\mathrm{x}$ New Zealand White; $\mathrm{PF}=$ Papillon $\mathrm{x}$ Flemish Giant; PN = Papillon $\mathrm{x}$ New Zealand White.

Bayomi et al., 2012; Eman, 2011; Abdel-Hamid, 2007; El-Shiehk et al., 1992 and Hemeda et al., 1992). The higher insignificant GCA at marketing age for FF (28.12) as compared to PP and NN (8.39 and -36.51, respectively) illustrated the higher additive effect for FF breed genes.

On the other hand, use of New Zealand White as sire breed with Papillon as dam breed (NP), showed superiority in marketing body weight rather than NF and FP crossbreds (29.42 vs -32.32 and -14.64 , respectively) indicating higher magnitude of dominance and epistatic effect for NP genes at marketing. The negative significant effect of reciprocal crossing on body weight at marketing of ages revealed the important role of breed utilization as a dam breed in crossbreeding program in case of improvement body weight at older age.

\section{Daily gain weight $(D G)$}

General and specific combining ability and reciprocal cross were found to be significant $(\mathrm{P}<0.05$ or 0.001$)$ on daily weight gain (DG), during 8-12 and 4-12 weeks of age (Table 7). 
Table 6. General combining ability, specific combining ability and reciprocal cross effects for live body weight (BW) on rabbits from weaning to marketing

\begin{tabular}{|c|c|c|c|}
\hline \multirow{2}{*}{ Breeding groups } & \multicolumn{3}{|c|}{ BW $(g)^{\text {a }}$ at: } \\
\hline & 4 weeks & 8 weeks & 12 weeks \\
\hline \multicolumn{4}{|c|}{ General combining ability } \\
\hline $\mathrm{NN}$ & 17.6728 & -21.1811 & -36.5182 \\
\hline PP & -23.3754 & -8.4811 & 8.3975 \\
\hline $\mathrm{FF}$ & 5.7026 & 29.6622 & 28.1207 \\
\hline Significance test & NS & NS & NS \\
\hline \multicolumn{4}{|c|}{ Specific combining ability } \\
\hline $\mathrm{NF}$ & -17.06 & -24.65 & -32.32 \\
\hline NP & -21.88 & -41.90 & 29.42 \\
\hline FP & -4.32 & -18.54 & -14.64 \\
\hline Significance test & NS & NS & NS \\
\hline \multicolumn{4}{|c|}{ Reciprocal cross } \\
\hline $\mathrm{FN}$ & 13.40 & -54.65 & -144.27 \\
\hline $\mathrm{PN}$ & -3.96 & -18.01 & -141.85 \\
\hline $\mathrm{PF}$ & -2.30 & -50.95 & -78.76 \\
\hline Significance test & NS & $\mathbf{N S}$ & $* * *$ \\
\hline \multicolumn{4}{|c|}{$\begin{array}{l}\text { a: Means in the same column within the same classification have bearing different letter } \\
\text { differed significantly; } * * *=\mathrm{P}<0.001 ; \mathrm{NS}=\text { Not significant } \\
\mathrm{NN}=\mathrm{New} \text { Zealand White; PP = Papillon; FF= Flemish Giant; NF= New Zealand White } \\
\text { Flemish; NP = New Zealand White x Papillon; FP = Flemish Giant x Papillon; FN } \\
\text { Flemish Giant } x \text { New Zealand White; PF = Papillon x Flemish Giant; PN = Papillon } \\
\text { New Zealand White }\end{array}$} \\
\hline
\end{tabular}

The results obtained showed higher additive effect and superiority of PP than NN and FF breeds in DG through the fattening interval of 4-12 wks ( $0.53 \mathrm{~g} /$ day vs 0.47 and $-1.00 \mathrm{~g} /$ day, respectively). On contrary, El-Bayomi et al. (2012) reported that breed differences in GCA for DG were nonsignificant at different ages.

The SCA effect showed superiority of $\mathrm{F}^{\lambda} \mathrm{x} \mathrm{P} \odot$ in DG during interval of 4-12 wks (1.52 g/day) than $\mathrm{N} \hat{\delta} \mathrm{X} \mathrm{P} q(0.38 \mathrm{~g} /$ day $)$ and $\mathrm{N} \delta \mathrm{X} \mathrm{F} q(0.48$ g/day). Similar results were reported by El-Bayomi et al. (2012) who recorded positive estimates of SCA for DG at most considered ages. 
Table 7. General combining ability, specific combining ability and reciprocal cross effects for daily weight gain (DG), on rabbits from weaning to marketing

\begin{tabular}{|c|c|c|c|}
\hline \multirow{2}{*}{ Genetic group } & \multicolumn{3}{|c|}{ DG $(g)^{a}$ from : } \\
\hline & 4-8 weeks & 8-12 weeks & 4-12 weeks \\
\hline \multicolumn{4}{|c|}{ General combining ability } \\
\hline $\mathrm{NN}$ & -0.73 & -0.77 & -1.00 \\
\hline $\mathrm{PP}$ & 0.28 & 1.40 & 0.53 \\
\hline $\mathrm{FF}$ & 0.45 & -0.63 & 0.47 \\
\hline Significance test & NS & $* *$ & $* *$ \\
\hline \multicolumn{4}{|c|}{ Specific combining ability } \\
\hline NF & 0.40 & 0.57 & 0.48 \\
\hline NP & -0.32 & 1.08 & 0.38 \\
\hline FP & 1.72 & 1.32 & 1.52 \\
\hline Significance test & NS & $*$ & $* * *$ \\
\hline \multicolumn{4}{|c|}{ Reciprocal cross } \\
\hline FN & 2.02 & 0.91 & 1.47 \\
\hline $\mathrm{PN}$ & 0.04 & -5.49 & -2.73 \\
\hline $\mathrm{PF}$ & -0.42 & 0.23 & -0.09 \\
\hline Significance test & $\mathbf{N S}$ & $* * *$ & $* * *$ \\
\hline \multicolumn{4}{|c|}{$\begin{array}{l}\mathrm{a}=\text { Means in the same column within the same classification have bearing different letters } \\
\text { differed significantly; } *=\mathrm{P}<0.05 \text { and } * * *=\mathrm{P}<0.001 ; \mathrm{NS}=\mathrm{Not} \text { significant } \\
\mathrm{NN}=\text { New Zealand White; } \mathrm{PP}=\mathrm{Papillon} ; \mathrm{FF}=\text { Flemish Giant; NF= New Zealand White } \\
\text { Flemish; NP = New Zealand White } \mathrm{x} \text { Papillon; FP = Flemish Giant } x \text { Papillon; FN }= \\
\text { Flemish Giant } \mathrm{x} \text { New Zealand White; PF = Papillon x Flemish Giant; PN = Papillon } \\
\text { New Zealand White }\end{array}$} \\
\hline
\end{tabular}

Present results cleared that use of $\mathrm{F} \circlearrowleft \mathrm{x} \mathrm{N} q$ cross is better than PN and PF crosses in enhancement of DG through interval 4-12 wks $(1.47 \mathrm{~g} /$ day vs 2.73 and $-0.09 \mathrm{~g} /$ day, respectively), which indicated, conclusively, importance of maternal effect on DG in rabbits. Previous results for different cross-combinations, showed some degree of variability in daily weight gain (Hemeda et al., 1992; Abdel-Hamid, 2007 and Eman, 2011). They concluded that the effects of SCA were highly significant on DG at most considered intervals ages. On contrary, El-Bayomi et al. (2012) found insignificant effect for the reciprocal crosses for DG. present results revealed the importance role of $\mathrm{P}$ breed in general and specific combining ability to improve of DG. 


\section{Relative growth rate\% $(R G)$}

In General, Table 8 exhibited significant effect for GCA, SCA and RC on RG during fattening intervals of 8-12 and 4-12 wks of age. The results illustrated the higher additive effect of $\mathrm{P}$ genes as compared to $\mathrm{F}$ and $\mathrm{N}$ genes (3.35 unit, $-0.21,-3.15$ unit, respectively). In an opposite result, ElBayomi et al. (2012) reported that breed differences in GCA for BW, were insignificantly through considered studied ages.

Table 8. General combining ability, specific combining ability and reciprocal cross for relative growth rate \% $(\mathrm{RG})$ of rabbits from weaning to marketing

\begin{tabular}{|c|c|c|c|}
\hline \multirow{2}{*}{ Genetic group } & \multicolumn{3}{|c|}{$\mathbf{R G}^{\mathrm{a}}$ at: } \\
\hline & 4-8 weeks & 8-12 weeks & 4-12 weeks \\
\hline \multicolumn{4}{|c|}{ General combining ability } \\
\hline $\mathrm{NN}$ & -2.84 & -1.09 & -3.13 \\
\hline PP & 1.84 & 2.51 & 3.35 \\
\hline FF & 1.00 & -1.42 & -0.21 \\
\hline Significance test & NS & $* *$ & $* *$ \\
\hline \multicolumn{4}{|c|}{ Specific combining ability } \\
\hline NF & 2.61 & 1.34 & 2.98 \\
\hline NP & 1.03 & 2.48 & 2.48 \\
\hline FP & 3.53 & -0.57 & 2.72 \\
\hline Significance test & NS & NS & $* *$ \\
\hline \multicolumn{4}{|c|}{ Reciprocal cross } \\
\hline FN & 2.07 & 1.53 & 0.93 \\
\hline PN & -0.61 & -8.28 & -6.20 \\
\hline PF & -1.80 & 0.43 & -1.23 \\
\hline Significance test & NS & $* * *$ & $*$ \\
\hline
\end{tabular}

a: Means in the same column within the same classification have bearing different letters differed significantly; $*=\mathrm{P}<0.05 * * *=\mathrm{P}<0.001 ; \mathrm{NS}=$ Not significant

$\mathrm{NN}=$ New Zealand White; $\mathrm{PP}=$ Papillon; FF= Flemish Giant; NF= New Zealand White $\mathrm{x}$ Flemish; NP = New Zealand White $\mathrm{x}$ Papillon; FP = Flemish Giant $\mathrm{x}$ Papillon; FN = Flemish Giant $\mathrm{x}$ New Zealand White; PF = Papillon x Flemish Giant; PN = Papillon $\mathrm{x}$ New Zealand White

The NF crossbred was found to be the best cross compared to NP and FP crosses as result to SCA on RG through fattening interval (2.98 unit vs 2.48 and 2.48 unit, respectively). In similar findings, Hemeda et al. (1992), Abdel-Hamid (2007) and Eman (2011) reported highly significant effect of SCA on RG at different studied ages.

Reciprocal cross effect revealed that FN crossbred is better than PN and PF for RG during intervals fattening interval at 4-12 weeks of age (0.93 unit vs - 
6.2 and -1.23 unit, respectively). This result highlights the importance of choosing the New Zealand White as a dam breed in crossbreeding program in case of desire to improve the relative growth rate.

Conclusively, the results obtained in present study suggested that Papillon is a promising breed in crossbreeding program regarding growth performance traits. Crossing of $\mathrm{N}$ as a sire breed with $\mathrm{P}$ as a dam breed, NP, would be recommended over other crosses to improve marketing weight in rabbits. However, crossing of $\mathrm{F}$ as a sire breed with $\mathrm{N}$ as a dam breed, $\mathrm{FN}$, would be recommended over other crosses to improve growth rate in rabbits especially in case of marketing rabbits at constant weight to save time and cost.

\section{REFERENCES}

Abdel-Hamid, T.M. (2015). Crossbreeding parameters for growth traits in a complete three breeds diallel cross design of rabbits in Egypt. J. Adv. Vet. Anim. Res., 2(2): 120-127. DOI: 10.5455/javar.2015.b60.

Abdel-Hamid, T.M. (2007). Genetic studies on some productive, reproductive and immunological traits in rabbits. M.Sc. Thesis, Faculty of Veterinary Medicine, Zagazig University, Egypt.

Adenaike, A.S.; Osisanyal, T.O.; Ogunsolal, O.D.; Asinel, A.O.; Whetol, M.; Ogunlakin1, D.O.; Amusan1, A.S. and Ikeobi, C.O.N. (2013). Combining ability and inheritance of growth traits in rabbits. Journal of Biology, Agriculture and Healthcare, Vol. 3, No. 13:102-107. Dickerson, G.E. (1993). Evaluation of breeds and crosses of domestic animals. Animal Production and Health Paper, 108. FAO, Rome. Italy. 47p.

Bora, M.; Goswami, R. N.; Das, D.; Zaman, G.; Das, A. and Nath, M. (2010). Combining ability effects on post weaning growth performance in terms of average daily gain in body weight in rabbit. Tamilnadu Journal of Veterinary and Animal Sciences, 6(6): 275-279.

Dickerson, G.E. (1993). Evaluation of breeds and crosses of domestic animals Animal Production and Health Paper 108. FAO, Rome. Italy. 47p.

Eady, S. J. (2003). Farmed rabbits in Australia. A report for the Rural Industries Research January, 2003 RIRDC Publication No 02/144 RIRDC Project No CSU-1A. Page 9-10.

El-Bayomi, K. M.; El-Tarabany, M. S. and Abdel-Hamid, T. M. (2012). Estimation of heterosis and combining ability for some weaning and post-weaning traits in three different breeds of rabbits. Journal of American Science,8(9): 282-288. 
El-Sheikh, A.I.; El-Bayomi, KH. M. and Hemeda, Sh. A. (1992). Combining ability and heterosis for slaughter performance and meat quality in three breed diallel crosses of rabbits. Proc. Fth Sci. Conf. Fac. Vet. Med. Assiut Univ., Nov. 8-10,1992, Egypt. 171- 178.

Eman, A. M. (2011). Heterosis and combining abilities of growth and carcass traits in different breeds of rabbits. M.Sc. Thesis, Fac. Vet. Med., Benha. Univ. Egypt.

Ezzeroug, R.; Belabbas, R.; Argente, M.J.; Berbar, A.; Diss, S.; Boudjella, Z.; Talaziza, D.; Boudahdir, N. and García, M.L. (2019). Genetic correlations for reproductive and growth traits in rabbits. Canadian Journal of Animal Science. 100: 317-322. https://doi.org/10.1139/cjas2019-0049.

Griffing, B. (1956 b). Concept of general and specific combing ability in relation to diallel crossing systems. Aust. J. of Biol. Sci. 9: 463-493.

Hanaa, A. Moustafa, El-Raffa, A.; Shebl, M.K.; El-Delebshany, A.; Nadia, A. and El-Sayed (2014). Genetic evaluation of some economic traits in a maternal line of rabbits. Egyptian Poultry Science Journal, 34 (I): $85-98$.

Hemeda, Sh. A.; El-Sheikh, A. I. and El-Bayomi, KH. I. (1992). Evaluation of combining ability and heterosis for weaning weight and post-weaning growth performance in rabbit crosses. Proc. Fth Sci. Conf. Fac. Vet., Med. Assiut Univ., Nov. 8-10,1992, Egypt. 171- 178.

Kabir, M.; Akpa, G.N.; Nwagu, B.I. and Adeyinka, I.A. (2011). Estimates of general and specific combining abilities for litter traits in $3 \times 3$ diallel crossing of rabbits: Proc. 36th Annual Conf. Nigerian Society for Animal Production (NSAP), Abuja, Nigeria, 2011b, 39-41.

Kabir, M.; Akpa, G.N.; Nwagu, B.I. and Adeyinka, I.A. (2012). Litter Traits in Diallel Crossing of Three Rabbit Breeds in Northern Guinea Savannah Zone of Nigeria: Proc.10th World Rabbit Congress WRSA, Sharm El-Sheikh, Egypt, 2012b, 69-74.

Ouyed, A.; Rivest, J. and Brun, J.M. (2011). Heterosis, direct and maternal additive effects on rabbit growth and carcass traits from a Canadian experiment. World Rabbit Sci. 19: 31-41.

Peiró, R.; Badawy, A.; Blasco, A. and Santacreu, M. (2019). Correlated responses on growth traits after two-stage selection for ovulation rate and litter size in rabbits. Animal, 13(11), 2457-2462. doi: 10.1017/ S1751731119001423.

Prayaga, K. C. and Eady, S. J. (2002). Performance of purebred and crossbred rabbits in Australia: doe reproductive and pre-weaning litter traits. Australian Jor. Of Agricultural Research, 54 (2): 159-166. 
Rania, A. Hassan (2005). Effect of crossing on productive performance of rabbits. MSc. Thesis, Faculty of Vet. Med. Suez Canal Univ. Egypt.

Rojas, B. and Sprague, G.F. (1952). A comparison of variance components incorn yield trials: 111. General and specific combining ability and their introduction with locations and years. Agronomy Journal, 44: 452-466.

SAS Institute Inc. (2011). SAS/STAT® 9.3 User's Guide. SAS Inst. Inc., Cary, NC, USA.

Sakthivel, M.; Balasubramanyam, D.; Kumarasamy, P.; Gopi, H.; Raja, A.; Anilkumar, R. and Devaki, A. (2017). Estimates of (co)variance components and genetic parameters for body weights and growth efficiency traits in the New Zealand White rabbit. World Rabbit Science,. 2017, 25: 329-338. https://doi.org/10.4995/wrs.2017.7057.

Shemeis, A.R. and Abdallah, O.Y. (2000). Possibilities of developing favourable body fat partition via selection indexes - Application on rabbits. Archiv für Tierzucht, Dummerstorf, 43: 193-201.

Sprague, G.F. and Tatum, L.A. (1942). General versus specific combining ability in single crosses of corn, Journal of American Society of Agronomy, 22: 320-326.

Tong, C.; Liu, G.; Yang, L. and Shi, J. (2012). "GSCA: New Software and Algorithms to Analyse Diallel Mating Designs Based on Restricted Linear Model" Silvae Genetica, 61: 126-132. https://doi.org/10.1515/sg-20120016.

Zigo F.; Pyskatý, O.; Šimek, V.; Ondrašovičová, S.; Zigová, M.; Takáč, L. and Takáčová, J. (2019). Comparison of exterior traits in selected large breeds of rabbits. Int J Avian \& Wildlife Biol.; 4(3): 96-100. DOI: 10.15406 /ijawb. 2019.04. 00159.

$$
\begin{aligned}
& \text { قرة التوافق العامة والخاصة لخصائص اداء النمو في الارانب }
\end{aligned}
$$

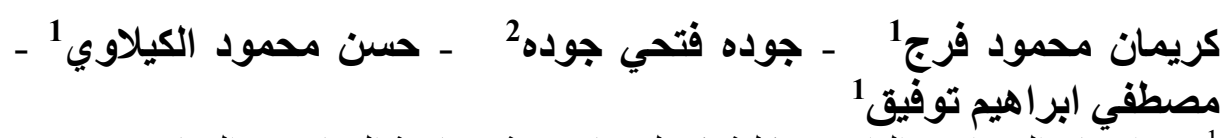

$$
\begin{aligned}
& \text { } 1 \text { قسم الانتاج الحيو اني و الداجني , كلية تكنولوجيا وانيا وتنمية , جامعة الز فازيق , الزقازيق , مصر. }
\end{aligned}
$$

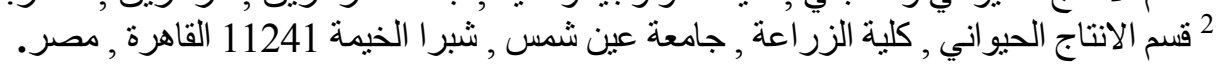

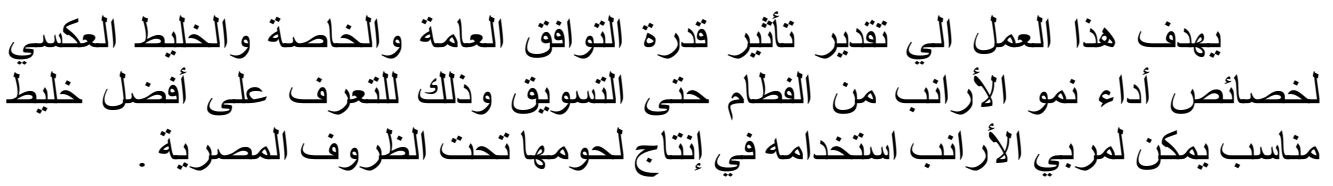




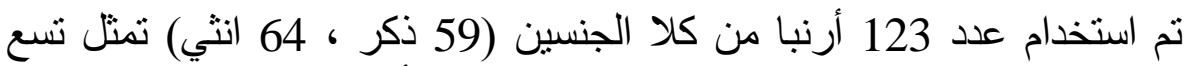

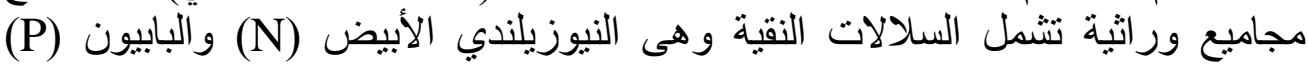

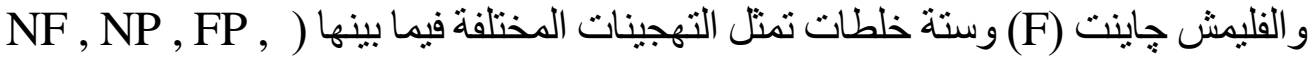
. ( FN , PN , PF

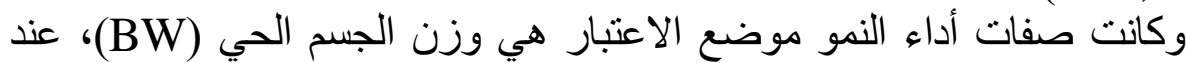

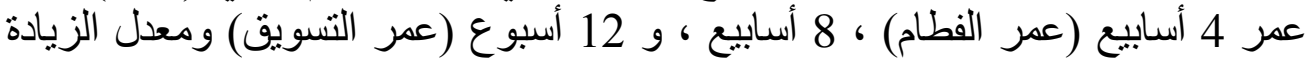

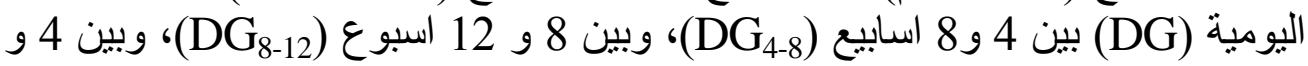

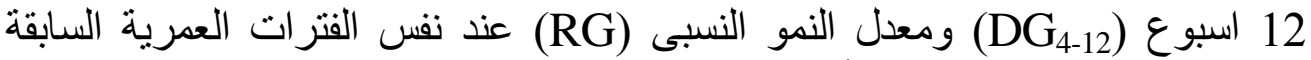

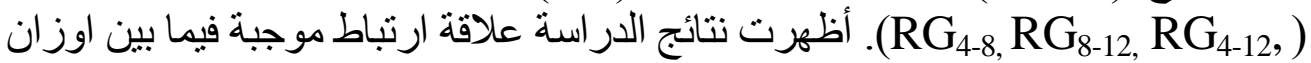

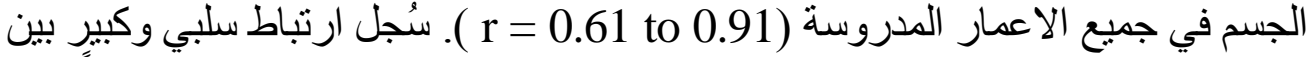

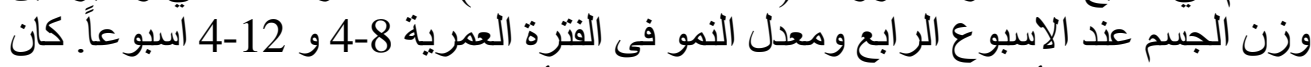

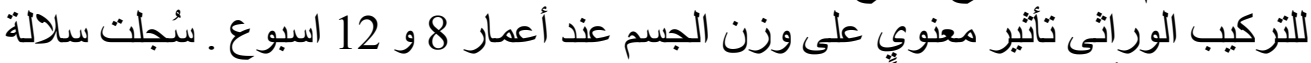

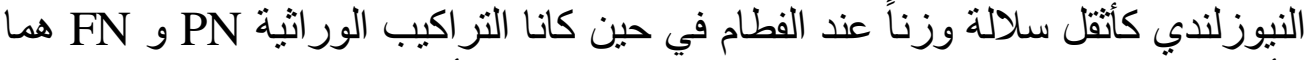

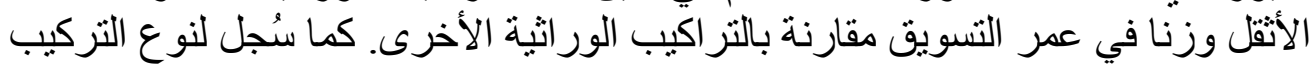

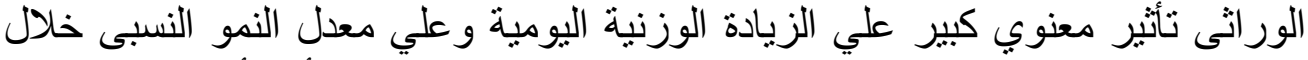

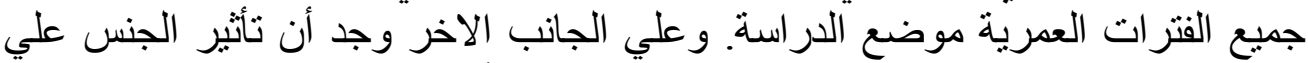
وزن الجسم وعلي الزيادة اليومية ومعدل النمو في الأرانب النامية غير معنوي خلال الأليال

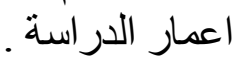

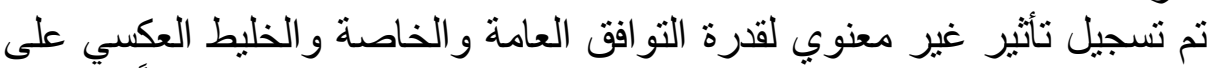

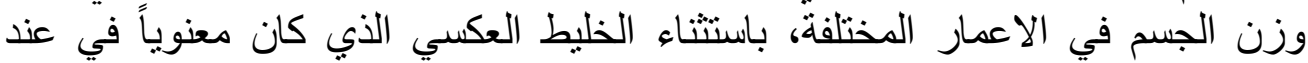

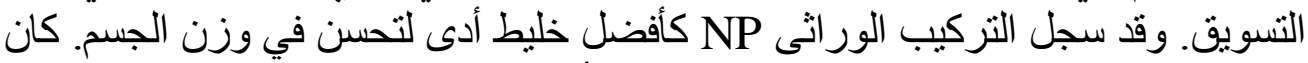

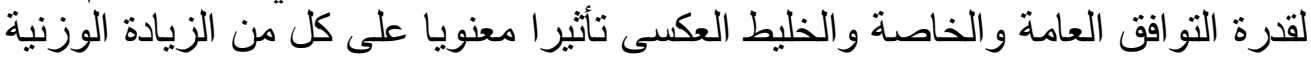
اليومية ومعدل النمو النسبى وقد تبين أن التركيب الوراثى FN هو أفضر النّل خليط في هاتين

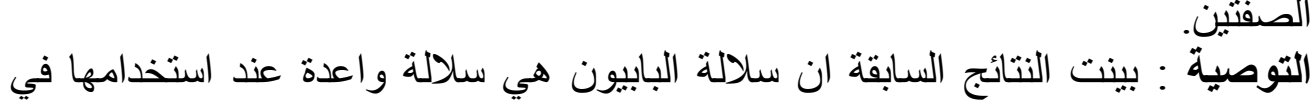

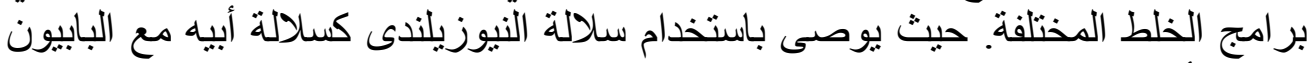

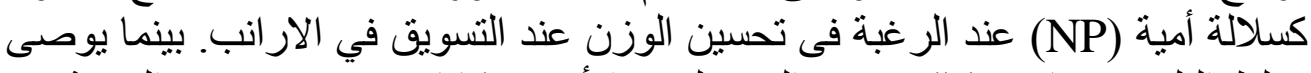

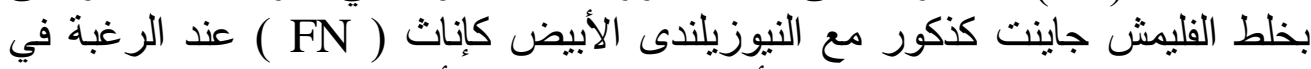

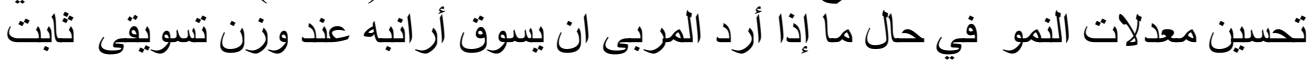
وذللك لتوفير الوقت وتكلفة التربية. الكلمات المفتاحية: أرانب ، صفات النمو ، قدرة التو الفق العامة و الخاصة . 

